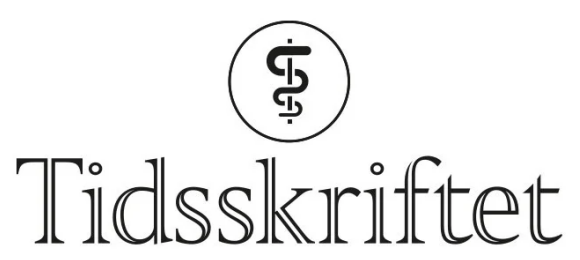

DEN NORSKE LEGEFORENING

\title{
Abstinensbehandling i praksis
}

DEBATT

ANDREAS WAHL BLOMKVIST

andreas.wahl.blomkvist@unn.no

Andreas Wahl Blomkvist er lege i rus- og avhengighetsmedisin ved Universitetssykehuset NordNorge.

Forfatteren har fylt ut ICMJE-skjemaet og oppgir ingen interessekonflikter.

\section{JANNE SPAUN}

Janne Spaun er spesialist i rus- og avhengighetsmedisin og konstituert overlege ved Universitetssykehuset Nord-Norge.

Forfatteren har fylt ut ICMJE-skjemaet og oppgir ingen interessekonflikter.

\section{LINE OLAISEN}

Line Olaisen er lege i rus- og avhengighetsmedisin ved Universitetssykehuset Nord-Norge. Forfatteren har fylt ut ICMJE-skjemaet og oppgir ingen interessekonflikter.

\section{MINNA HANSEN}

Minna Hansen er spesialist i rus- og avhengighetsmedisin og overlege ved Universitetssykehuset Nord-Norge.

Forfatteren har fylt ut ICMJE-skjemaet og oppgir ingen interessekonflikter.

\section{Alkoholabstinens er en dynamisk tilstand med varierende behov for medisinering. Etter vår erfaring er det ofte behov for større doser benzodiazepiner enn det som er angitt i de nasjonale retningslinjene.}

Alkoholabstinens oppstår når en person betydelig reduserer eller slutter å innta alkohol etter en periode med høyt inntak. Tilstanden forløper som regel uproblematisk, men kan få et alvorlig forløp med livstruende komplikasjoner. Nasjonal faglig retningslinje anbefaler innleggelse for pasienter med uavklart somatisk tilstand, risiko for alvorlig abstinenssymptomer eller som tidligere har hatt delirium tremens eller abstinensutløste kramper (1).

\section{Klinisk forløp ved alkoholabstinens}


Alkoholabstinens er dominert av autonome symptomer (takykardi, hypertensjon, tremor, svetting, kvalme, oppkast) og psykiske symptomer (angst, uro, agitasjon, søvnløshet, ulike typer persepsjonsforstyrrelser) (1). Symptomene forverres de første 2-3 dagene og avtar som regel etter det. Wernickes encefalopati, abstinensutløste kramper og delirium tremens er blant de viktigste komplikasjonene. Wernickes encefalopati skyldes tiaminmangel og kan debutere akutt med oftalmoplegi, ataksi (som ofte gir betydelige vansker med balanse og gange) og/eller forvirring. Abstinensutløste kramper ses typisk det første døgnet og er gjerne enkeltstående, kortvarige (under tre minutter) og generelle tonisk-kloniske (2) Delirium tremens forekommer vanligvis på andre eller tredje dag og gjenkjennes ved forvirring, fluktuerende bevissthetsnivå, livaktige hallusinasjoner og eventuelt autonom instabilitet (2).

\section{Nasjonale behandlingsanbefalinger}

Formålet med abstinensbehandling er å forhindre komplikasjoner og redusere abstinenssymptomer. Wernickes encefalopati bør rutinemessig forebygges med tiamininjeksjoner (intramuskulært eller intravenøst) på grunn av dårlig opptak i tarm og ofte tilgrunnliggende dårlig ernæringsstatus. Nasjonal faglig retningslinje anbefaler 100$200 \mathrm{mg}$ daglig i 3-5 dager (1․). Benzodiazepiner gir god symptomlindring og har en signifikant krampeforebyggende effekt (3). Dokumentasjonen for antiepileptika er svakere, og heterogenitet i studiene gjør at disse ikke er å foretrekke fremfor benzodiazepiner (4).

\section{"Vår erfaring er at vi ved å ha høyere maksdosering for benzodiazepiner oppnår raskere symptomkontroll hos pasienter som tidlig utvikler abstinenssymptomer»}

Alkoholabstinens er en dynamisk tilstand med individuell variasjon i behov for benzodiazepiner. En metaanalyse av kliniske studier tyder på at symptombasert dosering gir kortere behandlingsforløp og lavere behov for benzodiazepiner enn fast dosering (5). Symptomene kan graderes av personell med opplæring i bruk av standardiserte skjemaer, f.eks. Clinical Institute Withdrawal Assessment of Alcohol Scale (CIWA-Ar), der man graderer kvalme/oppkast, tremor, svette, angst, agitasjon, persepsjonsforstyrrelser og forvirring (appendiks) (므). Nasjonal faglige retningslinje anbefaler å styre doseringen etter CIWA-Ar-skår (1). Ved skår $<10$ foretas skåring hver fjerde time og ved $\geq 10$ hver time eller annenhver time. Doseringsanbefalingene for diazepam er gitt i tabell 1, men det anbefales å bruke ekvipotente doser oksazepam til eldre og personer med leversvikt. Til forebygging av delirium for pasienter som tidligere har hatt dette, anbefales det i nasjonal retningslinje å sikre nattesøvn med diazepam 10-20 mg på kvelden, eventuelt med tillegg av 10 mg hver time til pasienten får sove (1).

\section{Tabell 1}

Nasjonale og lokale (Avrusningsenheten ved Universitetssykehuset Nord-Norge) doseringsanbefalinger ved alkoholabstinens etter skår på Clinical Institute Withdrawal Assessment of Alcohol Scale (CIWA-Ar). Medikamentene gis peroralt med mindre annet er oppgitt.

\begin{tabular}{|lll|}
\hline CIWA-Ar-skår & $\begin{array}{l}\text { Nasjonale } \\
\text { doseringsanbefalinger }(1)\end{array}$ & Lokale doseringsanbefalinger \\
\hline$<10$ & Ingen medikamentelle tiltak & Ingen medikamentelle tiltak \\
\hline
\end{tabular}




\begin{tabular}{|c|c|c|}
\hline CIWA-Ar-skår & $\begin{array}{l}\text { Nasjonale } \\
\text { doseringsanbefalinger }(1)\end{array}$ & Lokale doseringsanbefalinger \\
\hline $10-15$ & $\begin{array}{l}\text { Diazepam } 10 \mathrm{mg} \times 4 \text {. Seponering når } \\
\text { CIWA-Ar }<10\end{array}$ & $\begin{array}{l}\text { Diazepam } 10 \text { mg hver time inntil } \\
\text { CIWA-Ar }<10 \text { eller pasienten sover }\end{array}$ \\
\hline $15-20$ & $\begin{array}{l}\text { Diazepam } 10 \mathrm{mg} \text { hver time inntil } \\
\text { CIWA-Ar }<10 \text {. Deretter } 10 \mathrm{mg} \times 4 \mathrm{i} 1- \\
2 \text { dager }\end{array}$ & $\begin{array}{l}\text { Diazepam } 15 \mathrm{mg} \text { hver time inntil } \\
\text { CIWA-Ar }<10 \text { eller pasienten sover }\end{array}$ \\
\hline$>20$ & Samme som over & $\begin{array}{l}\text { Diazepam } 20 \text { mg hver time inntil } \\
\text { CIWA-Ar }<10 \text { eller pasienten sover }\end{array}$ \\
\hline $\begin{array}{l}\text { Manglende } \\
\text { respons }\end{array}$ & $\begin{array}{l}\text { Ved manglende respons etter } 50 \mathrm{mg} \\
\text { diazepam: olanzapin 5-10 mg } \\
\text { intramuskulært eller peroralt. Gjentas } \\
\text { hver time til maks } 30 \mathrm{mg}\end{array}$ & $\begin{array}{l}\text { Ved manglende respons etter } \\
100 \text { mg diazepam gis olanzapin } \\
10 \mathrm{mg} \text { peroralt eller intramuskulært. } \\
\text { Deretter diazepam etter CIWA-Ar- } \\
\text { skår, inntil } 50 \text { mg. Deretter gjenta } \\
10 \text { mg olanzapin }\end{array}$ \\
\hline
\end{tabular}

\section{Vår kliniske erfaring}

Vi har ved vår avrusningsenhet ved Universitetssykehuset Nord-Norge tatt imot elektive og akutte pasienter fra hele regionen som trenger spesialisert abstinensbehandling. Vi har generelt gode erfaringer med de ovennevnte anbefalingene og opplever at somatiske og psykiatriske avdelinger i økende grad benytter seg av CIWA-styrt dosering av benzodiazepiner. Det er viktig å presisere at CIWA-Ar er veiledende og ikke erstatter klinisk vurdering. Dette gjelder særlig der pasienten har eksisterende plager, som eksempelvis tilgrunnliggende angstlidelse som gir utslag på CIWA-Ar, eller av ulike årsaker skårer annerledes enn man skulle forvente. Vi har god erfaring med å kombinere klinisk vurdering med CIWA-Ar-skår og eventuelt justere doseringene individuelt i vanskelige tilfeller. Ved bruk av oksazepam i abstinensbehandlingen bør man være oppmerksom på langsom absorpsjon (makskonsentrasjon 2-4 timer etter peroralt inntak) når man vurderer behandlingseffekt.

Noen pasienter utvikler abstinenssymptomene svært raskt, og vi har erfart at de nasjonale doseringsanbefalingene - med inntil 50 mg diazepam de første fem timene - ikke nødvendigvis gir tilstrekkelig symptomkontroll. Pasienter kan ha stigende CIWA-Ar-skår til tross for behandling, og disse har ofte høy risiko for abstinensutløste kramper og senere delirium tremens. Ettersom antipsykotika senker krampeterskelen og ikke er dokumentert for bruk i abstinensbehandling, har vi vært tilbakeholdne med antipsykotika, spesielt tidlig i forløpet.

Ved vår avrusningsenhet har vi justert doseringsanbefalingene for å ta høyde for dette (tabell 1). Vår erfaring er at vi ved å ha høyere maksdosering for benzodiazepiner oppnår raskere symptomkontroll hos pasienter som tidlig utvikler abstinenssymptomer, samtidig som eventuell medisinering med antipsykotika utsettes til etter at 100 mg diazepam er gitt - og dermed senere i forløpet. Ettersom søvn er viktig for forebygging av delirium (7.), har vi også poengtert viktigheten av å unngå unødvendige oppvåkninger. Pasienter som likevel utvikler delirium med dette regimet, trenger vanligvis sedasjon med andre midler enn benzodiazepiner (f.eks. propofol, ketamin, barbiturater eller deksmedetomidin). Disse må ha tett somatisk overvåkning på egnet avdeling. 
1. Welle-Strand G, Haugen S, Ohldieck C et al. Avrusning fra rusmidler og vanedannende legemidler. Helsedirektoratet. https://www.helsedirektoratet.no/retningslinjer/avrusning-fra-rusmidler-ogvanedannende-legemidler Lest 7.6.2021.

2. Wolf C, Curry A, Nacht J et al. Management of alcohol withdrawal in the emergency department: Current perspectives. Open Access Emerg Med 2020; 12: 53-65. [PubMed][CrossRef]

3. Amato L, Minozzi S, Vecchi S et al. Benzodiazepines for alcohol withdrawal. Cochrane Database Syst Rev 2010;3: CDoo5063. [PubMed]

4. Minozzi S, Amato L, Vecchi S et al. Anticonvulsants for alcohol withdrawal. Cochrane Database Syst Rev 2010; 3: CDoo5064. [PubMed]

5. Holleck JL, Merchant N, Gunderson CG. Symptom-Triggered Therapy for Alcohol Withdrawal Syndrome: a Systematic Review and Meta-analysis of Randomized Controlled Trials. J Gen Intern Med 2019;34: 1018-24. [PubMed][CrossRef]

6. Sullivan JT, Sykora K, Schneiderman J et al. Assessment of alcohol withdrawal: the revised clinical institute withdrawal assessment for alcohol scale (CIWA-Ar). Br J Addict 1989; 84: 1353-7. [PubMed] [CrossRef]

7. Walker M. Why we sleep: Unlocking the power of sleep and dreams. New York, NY: Scribner, 2017.

Publisert: 2. juli 2021. Tidsskr Nor Legeforen. DOI:10.4045/tidsskr.21.0423

Mottatt 20.5.2021, første revisjon innsendt 29.5.2021, godkjent 7.6.2021.

(C) Tidsskrift for Den norske legeforening 2023. Lastet ned fra tidsskriftet.no 26. april 2023. 